\title{
10 On saints, prophets, philanthropists, and anticlericals
}

\section{Orthodoxy, gender, and the crisis in Greece}

\author{
Eleni Sotiriou
}

The year 2018 marked a decade since the beginning of the economic crisis in the Eurozone, and Greece, its protagonist par excellence, is still living under its spell. "The crisis" ( $i$ krisi), as it is termed colloquially, became an everyday word in the vocabulary of modern Greeks and an allencompassing explanatory term for the drastic changes that occurred in their lives. The prolonged economic and financial crisis and its concomitant political, institutional, and societal ones are coupled with the migration/ refugee crisis that Greece has been experiencing since 2015. Currently, therefore, the country is facing not a single crisis, but a manifold one that withstands an easy definition. Its effects are multifarious, deeply enmeshed, and ever evolving, making their analysis and appraisal arduous.

This chapter is a first attempt to sketch and provide a "flavor" of the changes being brought about by the infamous Greek crisis on the religious beliefs, practices, and experiences of Greek Orthodox women and men: what changed, what form or forms these changes took, and how such changes have impacted on gender relations within the religious sphere.

\section{Studying the Greek crisis}

Over the last few years, a host of studies have been produced on Greece, analyzing the socioeconomic transformations brought about by the crisis from different disciplinary lenses and intellectual viewpoints. Yet, this current academic interest in the crisis has mostly suffered from what Ursula King $(2005,1)$ refers to as "double blindness": being either religion or gender blind, it has yet to produce a study (outside the field of theology) that focuses on the entanglement of the crisis in the complex relationship of Greek Orthodoxy and gender. ${ }^{1}$ I argue that gender and religion require careful remapping in times of crisis, linked as they are to new attitudes and changed practices that often go undetected; studying their interplay can serve to illuminate the nuances of the ways in which preexisting inequalities are either reconfirmed, defended, and reenforced or negotiated anew. My intention, however, is not simply to adopt a power perspective 
on how the crisis affects the relationship of Greek Orthodoxy and gender, but to use ethnographic detail to synthesize such an approach with the actual practices and the meanings attached to them by my female and male interlocutors. ${ }^{2}$ My emphasis is thus on "lived religion" (McGuire 2008) and lived experience of the crisis.

The data on which my observations are based derive from ethnographic research conducted periodically from 2014 to 2017 in Larissa, the capital and largest city of the Thessaly region. As a researcher, the Greek religious landscape is an area I am well familiar with, since from the early 1990s I have investigated various aspects of the religious lives of Greek Orthodox women and men, both lay and monastic. My long-term engagement with the topic of gendered religiosity, as well as my Greek origin, has honed my ability to recognize the complex and subtle changes and transformations that the Greek crisis precipitated.

During the crisis years, Larissa, which in 2011 had a population of 144,651 (census 2011), has shrunk demographically and lost its economic vibrancy (mainly commercial and agricultural). Somewhat paradoxically, during the recession the city's economy has shifted to recreation, leisure, and particularly to food services, altering its identity and transforming its center "from a district of productive economic activities to a district of symbolic economy and leisure" (Manika and Gospodini 2015, 68).

The city's Cathedral of St. Achillios, the main locus of its religious life, provided the site of the ethnographic vignettes outlined here and the main meeting place with my interlocutors. These were both men and women of different generations (from 22 to 81 years old). In my analysis, those under the age of 40 are categorized as "younger" women and men, while the rest belong to the "older" generation. Most of my interlocutors come from a middle-class social background and the majority of them hold university degrees. ${ }^{3}$

At this point, a number of clarifications are necessary concerning my use of the main concepts of this chapter: crisis, religion, and gender.

First, I treat "crisis" not simply as an event of momentous changes, a snapshot of Greece's present, isolated from its past, but rather as a process that simultaneously creates and reveals multileveled asymmetries, cultural contradictions, and new opportunities (Dalakoglou, Agelopoulos, and Poulimenakos 2018, 11).

Second, in spite of recent changes, especially due to the various migration waves since the 1990s and the recent migration/refugee crisis that led to an increased presence of other religions in the country, Greece remains predominantly Orthodox. A poll by КАПА Research shows that 81.4 percent of Greeks still consider themselves as Orthodox Christians (Chiotis 2015). More important, though, than the language of statistics is the fact that when my interlocutors talked about religion, they talked about Greek Orthodoxy. Thus, when I use the term "religion," it is to this emic interpretation that I refer to. 
Third, I do not treat gender only as synonymous to women (King 2005, 5). At present, a big gap exists in most anthropological studies on Greek Orthodoxy and gender: that of the "ordinary religious man." The Other of the Greek Orthodox woman has mainly been the male cleric, while ordinary laymen have been treated as peripheral, only discussed either in relation to their numerical inferiority in the church and/or to their anticlerical feelings. My analysis, however, points to the necessity of bringing laymen into the picture. In fact, I would argue that as the sweeping social and economic changes unleashed by the crisis filtered slowly through the religious sphere, both men and women had to reconfigure their relationship to religion in general and to the church in particular, and specifically in the case of men, to redefine their masculinity. Crucial to my purpose is also the need to move beyond homogenized social categories and simple dyadic oppositions such as men/women and to take into account other determinants of identity. Here, perhaps even more than anything else, age matters. Particularly, as far as women are concerned, paying attention to the women under 40 generates a whole new picture of "doing" religion and gender in times of crisis, prompting us to reconsider the feminization of Greek Orthodoxy.

Scholars of gender and religion have often expressed the urgent need to overcome the rigidness of dualistic interpretations, focusing instead on "the motivations, desires and goals" that might otherwise remain unexplored (Mahmood 2006, 38; see also Gemzöe and Keinänen 2016). This line of argumentation is particularly pertinent to my discussion of victimhood and agency, both in the religious and the wider Greek social context. Greek women and men are not passive victims of the drastic changes and rapid transformation of power structures brought about by the prolonged crisis in their country. Rather, victimhood must be seen in this context not as completely devoid of agency. Both victimhood and agency are tactical mechanisms adopted by Greek men and women vis-à-vis the church, the state, and the broader international community.

Finally, this study bears upon wider issues, both internal and external, such as the intricate interweaving of Greek Orthodoxy and Greek nationhood, the close relationship of church and state, and the alterity of the Orthodox East vis-à-vis the Latin West. Because of its geopolitical position and history, Greece continues to be regarded as a hybrid of elements from both East and West. After the foundation of the Modern Greek state in the nineteenth century, Orthodoxy became central to the official public discourse and instrumental in the diachronic preservation of Greek national identity. The very close connection and mutual legitimation between church and state corroborated this relation and deployed it against various perceived enemies, which were mostly thought of stemming from Western Europe/the West. Historically speaking, East-West relations have always been tense. The Greek Orthodox were often suspicious or even dismissive of Western ideas and influences, including modernity and secularism, whereas their Western counterparts regarded Greeks as tradition-bound 
and lagging behind. Although the Modern Greek state kept close ties with the West, anti-Western and anti-European mentalities and orientations, Orthodox and otherwise, prevail to this day. An outburst of such attitudes can be particularly observed during the recent Greek crisis.

\section{The gendered face of the crisis}

While there is no agreement on exactly when the Greek crisis began and no shortage of scenarios as to who should be held accountable for it (lazy and unproductive Greeks, corrupt politicians versus the Troika, neoliberalism, the Great Powers-to name but a few), all scholars and analysts agree that this crisis has an intensity unmatched by any other EU country. Austerityridden Greece has become the scarecrow of the Eurozone: an exemplary failure, spreading fear and uncertainty for the future of the EU, yet peripheral and marginal enough (geographically and financially) to become the testing ground of a number of neoliberal policies (see Knight 2013).

Both internationally and locally, Greece is portrayed as an exceptional case due to its economic, political, and cultural idiosyncrasies (Rakopoulos 2014, 191-194). This enables discourses of governance and media narratives based on generic concepts and categories such as "the Greek crisis" and "the Greek people." Simultaneously, the crises of different gendered, classed, and racial subjects, during what were termed as "exceptional times," "critical weeks and months," and a "state of emergency," were sidelined, and these people's needs were sacrificed on the altar of overall economic necessities as dictated by the white and predominantly male governing elites. Yet, like the economic and financial crisis of the rest of the Eurozone, the Greek crisis is both "gendered and gendering" (Kantola and Lombardo 2017, 5).

The overall picture is bleak for both women and men. The crisis-austerityrecession environment in Greece brought about high rates of unemployment combined with falling wages, an increase in working hours and loss of benefits, cuts to public services and welfare provisions, cuts in health care and pensions, and increased taxation. Women became progressively the shock absorbers of austerity and recession measures, the most vulnerable being the young (25 and under), single mothers, pensioners, and migrant women (Karamessini 2014, 173; Bakalaki 2015).

The lower quality of life and precarious work resulted in the deterioration of the physical and mental health of the general population and in an increase of what has been termed "economic suicide" rates, particularly among men (Harrison 2015). This is also due to the persistence of the male breadwinner model that was dominant even before the crisis, and to the reinforcement of traditional gender roles that allocate the major responsibility for the children, the ill, the elderly, and the care for the home to women. Before the crisis, this work was largely assumed by migrant women (Papataxiarchis, Topali, and Athanasopoulou 2009). However, as the welfare state deteriorated, the "new poor"-that is, middle-class Greek 
women-are undertaking such work themselves. The return to traditional values thus exacerbated gender inequalities and undermined the modest advances toward gender equality made in pre-crisis Greece. ${ }^{4}$

This is also attested by the alarming increase in violence against women, both in the public and in the domestic domain. In 2012, two women politicians were attacked on live television by a leading figure of the neo-Nazi party Golden Dawn, who later became a member of the Greek Parliament when his party won 7 percent of votes in the elections of the same year. The aggressive male chauvinistic ideology of the extreme right is a sign that Greek men are seeking to regain the masculinity stolen from them by the crisis.

My male Larissean interlocutors also think of the crisis as entailing a sexual assault (mas exoune gamisei), an act of sodomy (Bakalaki 2015). Given that Greek men have always viewed themselves as the defenders of the nation (partly due to their compulsory military service), such blows on masculinity are regarded as blows to the nation as a whole and are evaluated in terms of the values of honor and shame. The international politicoeconomic elite shames the imagined male national self, and the blame is directed not only outwards but also inwards against Greek women. As Alkis, a 48-year-old doctor, jokingly commented: "fire, woman, sea, and the crisis-all evil things are gender feminine." Alkis has added the crisis to the commonly used anti-feminist proverb in Greece "fire, woman, and sea, three evils," alluding to their feminine grammatical gender in Modern Greek. ${ }^{6}$ In this context, women are blamed for the economic crisis since they are associated with overspending and having a taste for luxuries. ${ }^{7}$ Thus, the domestication of women becomes once again the solution to the ills of the crisis.

Interestingly enough, not only the language but also the very conceptualization of the Greek crisis is gendered. Larissaean women, particularly the older ones, talk about the crisis in terms of feeling "confined" (perioristikame), both economically and spatially, since getting out of the house involves the danger of spending money otherwise required to cover basic needs. This confinement is conceived of as a punishment for the excesses of the past as well as a cure that will bring about a better future. However, such logic is contested by many, especially the young, who see no future and are infuriated with those in power and their bending attitude toward the West. ${ }^{8}$

\section{The church, the crisis saints, and the crisis prophets}

The Greek Orthodox Church, including its finances, was also seriously affected by the crisis. Yet, the crisis offered the church a unique opportunity to become a key provider of philanthropic services throughout the country, replacing the state and collaborating with secular actors. Given its strong connection with the Greek nation, the church thereby appeared 
to fulfill its traditional role not only as the mother of the nation, but also as "the people's mother" (Makris and Meichanetsidis 2018). At the same time, the church focused on the spiritual side of the crisis, considering it as a theodicy, a pedagogical punishment from God, and demanding for a return to traditional Orthodox values, including gendered ones (Kessareas 2018). In this way, the crisis was portrayed as a disease, the church as its doctor, and charity as its medicine (Makris and Bekridakis 2013, 121). The crisis had significant repercussions on the way that many Greeks view the church, not only in institutional but also in spiritual terms, and on how they practice their religion. It is against this background that my interlocutors are "doing" religion and gender in their quotidian lives.

Attending services at St. Achillios, I witnessed a scene quite unfamiliar to the pre-crisis one. Timothy Ware (1997, 269-270), describing the effect of the absence of pews in Orthodox worship and commenting on its flexibility, informality, and homeliness compared to that of Western Christianity, writes:

Western worshippers, ranged in their neat rows, all in their proper places, cannot move about during the service without causing a disturbance; a western congregation is generally expected to arrive at the beginning and to stay to the end. But in Orthodox worship people can come and go far more freely, and nobody is greatly surprised if they move about during the service. (...) They are at home in their churchnot troops on a parade ground, but children in their Father's house.

The picture today appears to be different. Chairs are arranged in rows, in every available space within the church. Almost everybody is sitting in silence, participating in the outward and audible prayers and singing of the Liturgy, while kneeling-one of the most visible, outward bodily expressions of prayer-is restricted because of the seating arrangements and confined only to bowing one's head as a sign of devoutness, humility, and participation. Given that bodily movement in Orthodoxy is an "enacted symbol" of liturgical participation (McDowell 2013, 79) used among the laity, especially by women, such seating arrangements have gender implications for they circumscribe women's ritual space; so almost all liturgical movement is embodied by the male priests, deacons, and altar boys.

This is not to suggest that such changes are a direct consequence of the crisis or that they can be observed in every church throughout Greece. Still, for my interlocutors, there is a connection between the more orderly liturgical practices and the reverberations of the crisis on the individual body and the body politic. In the words of Anna, a 43-year-old teacher:

Sitting helps my mind to better concentrate on prayer that we all so much need to give us strength in these troubled times. My body can relax, I feel less tired, and I can more easily follow the Liturgy. I like the 
order that exists now in the Church. It shows what we should all do in our lives. It is the anarchy that existed in our country that brought us to the situation that we are now in.

If we acknowledge that religion is both in the "heart" and in the "knees" (Sakaranaho 2011, 142), the changes mentioned above, simple as they may be, should not go unnoticed. They reflect the need for deeper transformations within Greek society at large. Anna's statement echoes those of the EU institutions demanding that Greeks "put their house in order." As Father Georgios told me, "the Church should be the first to give an example of order and discipline." Paradoxically and ironically, order and discipline, two elements more typical of Western Christianity, are thus observed even within one of the pillars of Greek alterity vis-à-vis the West, namely the Orthodox Church.

The image of the laity, sitting with their heads bowed, is an image of a nation tired and crushed. The church, in its effort to help the people, has multiplied the number of services, adding all-night vigils and intercessory prayers to the Mother of God and to the saints. In the Cathedral of St. Achillios, the most popular of all services is the intercessory prayers to St. Luke the Surgeon (Agios Loukas o iatros), an Orthodox saint (1877-1961) from Crimea, who was a medical practitioner believed to have performed many healing miracles and a bishop persecuted by the Communist regime. Although this prayer service was introduced in 2007, the year that the saint's relics were brought to St. Achillios to be venerated, its popularity has greatly increased during the crisis, pointing to the main concerns and needs of the congregation and its reaction to current events. As Nikos, a 52-yearold bank clerk, remarked, "we attend this prayer service because the crisis made all of us sick." His comment is suggestive not only of the detrimental effects of austerity on the mental and physical health of the population, but also of the pathology of a corrupt state that cannot care for its citizens. As Father Georgios pointed out to his parishioners: "Demand from God and the saints, not from the state." The crisis has become chronic, and its routinization and naturalization have relinquished hope to the metaphysical domain. ${ }^{9}$

More importantly, in this parish the prayer service to St. Luke attracts even more people, both male and female, than the intercessory prayers to the Panagia (Mother of God). In Orthodoxy, the Mother of God is venerated above all saints. She has traditionally provided the main model for the ministry and role of women, both in church and society (Sotiriu 2004, 501). Prayer services to the Mother of God are vital for women, who are the main participants and chanters of these prayers, since they provide a unique female performative space within the formal space of the church (Glaros 2011, 139). This is not to say that the exalted position of the Panagia in the spiritual realm and in the hearts and prayers of both men and women has in any way diminished, but rather that the intercessory prayers to St. Luke are 
thought to be more suited to the pathology of the crisis. Nevertheless, this practice further restricts women's already limited location within formal liturgical practices. Their ritual performative expertise is slowly eroding, resembling more and more the passive liturgical participation of laymen.

While male saints cure, the words of male prophets such as those of Elder Paisios, a Greek monk from Mount Athos who died in 1994 and was canonized in 2015, are used to make sense of the experience of living in an uncertain present, "in an enduring attitude of expectant waiting" (Guyer 2007, 414). ${ }^{10}$ Paisios is said to have predicted the economic crisis, the future of the EU, and the eventual building of a modern Greek "Byzantine" Empire. Prophecies are crucial because they are gendered (Nissinen 2017, 297). In contemporary Greek Orthodoxy, in particular, the prophetic realm remains exclusively male, connected primarily to the powerful spiritual elders of Mount Athos.

My male interlocutors often discussed such prophecies and predictions of things to come. Such discussions pointed to the need to suffer and repent for desiring material excesses and often involved not only self-blaming, but also the blaming of Others glossed in conspiracy theories of imagined foreign plans and desires to destroy Greek Orthodoxy-the sole bastion of authentic Christianity. Though such prophecies were circulating among believers even before the Greek crisis, their ambiguous wording was interpreted anew to refer to current political and socioeconomic conditions, producing a climate of quasi-certainty where divine justice will prevail and Greece, the now European outcast, will relive the golden age of a distant past. In this sense, the current "social turmoil is not (only) embodied alongside past crises," as Knight $(2013,153)$ argues, but also emotionally experienced alongside past glories.

Yet, such expectations of a glorious future foster the same nationalistic, racist, sexist, and homophobic discourses actively promoted by the Golden Dawn party and various Orthodox ultraconservative groups. My male interlocutors do not identify with any of these groups. They rather think of themselves as devout Orthodox and separate themselves from the above-mentioned groups in terms of action. They are proud Greeks and Orthodox and at the same time pacifists, traditionalists, and modern Europeans, believing and discussing the prophecies not only of Orthodox elders, but also of leading local, European, and international economists and politicians. ${ }^{11}$ Curiously enough, the women of my study rarely discussed such religious prophecies; this may suggest that men use such mechanisms to reimagine the masculinity of a threatened Orthodox national self.

When I asked Father Georgios to comment on the current growing popularity of Elder Paisios and St. Luke among his parish members, he offered the following explanation: "It is because they are contemporary saints. Both lived during the twentieth century, and many people feel closer to them. Some men have even met Elder Paisios when he was alive during their pilgrimage to Mount Athos." Given the fact that far fewer female saints 
have been canonized by the church, particularly in recent periods, the prevalence of male saints in the Greek Orthodox scene is of no surprise. Their temporal proximity brings the two saints closer to the individual and the collectivity, facilitating communication with the divine world. In the case of St. Luke-an imported saint from the Russian Orthodox Church-not only his believed therapeutic powers make him an ideal helper, but also the fact that he lived and suffered under the Communist regime. My interlocutors imagine and recount his suffering as analogous to their own in the current socioeconomic circumstances. In his saintly persona, medicine, miracle, suffering, contemporaneity, and anti-establishment attitudes are thus combined, granting him a unique relevance to the current crisis. ${ }^{12}$

The popularity of the two saints is an example of what I term "adjustment tactics," by which the laity try to adapt to and make sense of the changes occurring in their everyday experience. Such tactics are further fostered and validated by the church because of their connection to both nationalism and paternalism. The nation is under attack and its male breadwinners at a loss. Male role models that are at the same time "ordinary people like us" (because of their corporeality and temporal proximity) and extraordinary (because of their virtuoso asceticism and self-discipline-culturally, a male trait much needed in times of economic hardship) are held up for emulation, help, encouragement, and hope for the future.

\section{Feminized men and disenchanted women}

The increasing importance of male prophets and male saints is connected to another, even more crucial, effect of the crisis. The Orthodox Church, to date a "feminized church"-in terms of women's active participation and numerical prevalence in church attendance, the sacraments of confession and communion, and pilgrimage-seems to be slowly losing its feminine touch. Studies on European Christianity's feminization abound and, as Linda Woodhead $(2008,188)$ has declared: "The typical churchgoer in Europe is now an older woman." 13 While my ethnographic study confirms this, a more nuanced analysis through the generational lens shows that, under the adverse conditions of the crisis, more men are attending church and participating in the sacraments, particularly among my younger interlocutors. Almost all of these men were university graduates. Some were in search of their first job while the ones already employed had seen significant wage cuts; two of them had even lost their jobs and been forced to accept part-time lower paid ones. Enquiring about their increased participation in church-related activities, I received the following answer from Father Georgios: "The Church has become the new Department of Social Security (tameio anergias)."

As victims of economic hardship and professional insecurity, men are more inclined than before to get actively involved in church-related activities, seeking to extend their social circle, solidarize with other men facing 
similar financial and emotional distress and-through their contact with the clergy-increase their chances of finding employment and financial support. ${ }^{14}$ The threefold increase of men joining the priesthood during the crisis period (Stamos 2015) provides additional proof that the financial benefits drawn by men from their religious involvement should not be overlooked.

Nevertheless, personal material gain is not the sole reason of men's growing involvement in the religious sphere. As Marja-Liisa Keinänen (2016, 68) appropriately argued, "religion does not exist in a social vacuum but is socially embedded and practiced." Thus, men's material and social needs do not preclude their spiritual ones, as is made clear by their increased participation in the sacrament of confession, in which previously older women prevailed. Men's quest for a spiritual father is not a new phenomenon, neither a direct consequence of the crisis. It is often connected with the access that men have to supposedly "superior" spiritual fathers, that is, the elders of the all-male monastic communities of Mount Athos. Such confessions are regarded as offering a superior moral guidance to that available to women by the parish priest.

Confession to the parish priest, however, is usually regarded as running counter to ideas of normative masculinity, as it entails the intimate disclosure of the inner self to someone whom men often criticize as not having to endure the financial hardship they face and whom they regard as closer to the older women of the parish. ${ }^{15}$ The men of my study increasingly embraced such practices for several reasons. First, because of their devoutness and will to "do things the right way," which included going to confession before receiving Holy Communion. Such an attitude has been more vigorously adopted by men since the crisis began and is the result of the official church discourse of treating the crisis as a theodicy. Second, confession allowed men to get closer to the parish clergy, meaning easier access to certain economic and social privileges. Finally, many likened confession to a psychotherapy session, as it created a secure offstage space for revealing their embarrassments, anxieties, and fears about being unable to be "real men" in terms of providing for themselves and their families. After confession they usually felt empowered to face their situation anew. ${ }^{16}$

Men's numerical participation in Sunday school and in the social and philanthropic work of the parish has also augmented in the last years. Perhaps the most striking observation coming from my ethnographic research is the complete absence of women from the parish's social work for the ill and the elderly. Taking into account that both in secular society and in the church's philanthropic domain, practices, and ideologies of caring remain strongly associated with women, this development is rather atypical. ${ }^{17}$ The group of volunteers responsible for the care of the old and the sick on the parish level was composed of ten younger men that visited and offered their services to those in need once a week. My male interlocutors agreed that care work was largely feminine and that women "know how to do it better." Yet, they viewed such work as "work for the soul." In times when 
secular work is hard to find or downgraded, it is replaced by spiritual work to confer value and self-worth. Thus, the church's provision of care for the sick and the elderly provided men with the opportunity to override traditional gender stereotypes and to reveal new, more feminine elements of their identities.

This new role of men, however, was not entirely dependent on men's volunteerism, but also on women's active rejection of participation in this specific philanthropic activity. My female interlocutors claimed that, since the crisis, they were overburdened with such care work in the domestic sphere. Viewing the crisis as instigating "a state of depression," they preferred to spend their free time in what they regarded as "more fun" philanthropic activities-such as working as a volunteer in the Epiousios soup kitchen administered by the Diocese of Larissa and Tyrnavos. Epiousios (literally meaning "daily bread") was established by the local church in 2002 , initially offering 150 daily meals to the destitute, the homeless, and the lonely of the diocese. In 2017, after almost ten years of economic devastation, the number of meals exceeded 450 . Taking weekly turns, volunteer women of different parishes in the diocese engaged in the soup kitchen, cooking the daily meal for what the church considered as "the larger family of the poor." These women were usually the older women of the parishes of the diocese, aged 50 years and over, and most of them were either noikokyres (housewives), pensioners, or unemployed due to the crisis.

For my female interlocutors, participation in the soup kitchen was a positive experience. It was not simply seen as an extension of women's domestic roles and a locus of female sociability and mutual support; more importantly, it was a sphere of action involving creativity, strategic planning, agency, and what it means "to do something out of choice." In their task of organizing menus with few ingredients and debating with other female volunteers and male administrators and clerics on ways to feed an ever-growing number of people, the women felt creative, productive, happy, and above all both spiritually and socially worthy. They were the main actors in what the local bishop called "the miracle of the pot." They engaged in cooking for the larger family of the poor as "mothers," and this symbolic motherhood was based more on an "ethic of choice" than an "ethic of service" (Paxson 2004). Food is, among other things, a marker of social injustice. By engaging in food caring as volunteers, these women were asking not only to be seen as autonomous individuals free to choose, but also as religious and political actors involved in a critique, however diffused, of austerity measures. ${ }^{18}$

Despite the rising involvement of laymen in church-related activities and philanthropic tasks, the dedication, participation, and religious expertise of these older women ensure that philanthropy and religion in crisis-ridden Greece maintain their feminine character. Yet, many feminine aspects of Greek Orthodoxy are becoming increasingly less apparent not only because more laymen are turning to religion during the crisis for spiritual 
and secular reasons, but also because of the changing religious attitudes, beliefs, and practices of younger women.

Among my interlocutors, the most outspoken critics of the church's handling of the crisis were the educated, middle-class women under the age of 40 . As we have seen, the church purports a return to traditional gender values as an important remedy to the afflictions of the crisis. Often, in their preaching to the churchgoers, priests laid the blame for "the current difficulties faced by Greek families" explicitly on women. In the words of one priest:

I am not sure that the story of Eve is without relevance in our times; many current evils came from the desire of Greek women to emulate imported modern ideas of womanhood. These led them to idealize work at the expense of the family. The cure is to reprioritize their roles as wives and mothers, using as role models the Mother of God and the many female saints of Greek Orthodoxy.

Predictably, such views that call for the domestication of women do not go down well with younger female churchgoers, even the devout ones, and they are either totally ignored or rejected as outmoded and degrading. Younger women regard priests, particularly the unmarried ones-who hold higher positions within the church hierarchy-as "coming from another world." However, their reaction is not so much against the individual parish priests, but against the church as an institution, its leaders, and its perceived intimate relation with the state. The statement by Stefania, a 33-year-old doctor, is a case in point:

During the crisis, the Church has positioned itself not on the side of the people but against them. It has collaborated with the corrupt leadership of the state in order to keep its vast wealth. It has avoided paying the heavy taxation that we, common people, have to pay.

Such anticlerical sentiments are widespread among the Greek population as a whole and have been heightened during the crisis, focusing mainly on the church's avoidance of direct political criticism of the state's responsibility for the country's financial collapse and the economic benefits that the church is able to gain from its position vis-à-vis the state (the priests' state salaries and pensions, church taxation, etc.). ${ }^{19}$ Furthermore, my interlocutors criticized the church's philanthropic response to the crisis as inadequate in comparison to its vast wealth. This reveals that top-down philanthropy does not hold the same moral value as giving from the bottom-up, and in this respect the church will always fall short, whatever its crisis-related initiatives.

These popular anticlerical sentiments were almost never against Orthodoxy as such. Nonetheless, they produced different modalities of religious 
engagement among my male and female interlocutors as well as intergenerational differences between the women. More specifically, among frequent male churchgoers, both young and old, and among older women, anticlerical sentiments were more related to general crisis sentiments and were expressed as verbal criticism against generic power structures such as the state and the church. Religious practice, however, did not seem to be affected by such sentiments, and the men tended toward "orthopraxy" and full embracement of the current official church discourse.

Younger women's anticlericalism, in contrast, was influencing their behavior vis-à-vis Orthodoxy. During the crisis, the reaction of my younger female interlocutors against the male dominance of the church has become more noticeable, exemplified in a more individualized form of Orthodox religiosity and also through the fusion of Orthodoxy with other forms of spirituality that fall under the umbrella of New Age-yoga, meditation, reiki, feng shui, and veganism being the most popular ones. Such practices have also been described as "a Greek spiritual revolution." Eugenia Roussou $(2013,48)$ argues that younger women "have begun to revolutionize Greek religiosity and their gendered identity, because they challenge the authority of the priests, their husbands, and of Orthodox Christianity."

Certainly, the transformation of younger women's religiosity is not wholly the outcome of the gendered consequences of the crisis in the religious sphere. Such changes are not isolated instances, and are partly due to larger processes of globalization and secularization and to the emanating shift from the Orthodox construction of relational personhood to "the imported construction of the individualistic human subject" (Hirschon 2010, 306). Yet, the growing economic and social vulnerability of these women during the crisis and the dissemination of secular and religious discourses that focus on their "essential" domesticity increased their disenchantment with Orthodoxy, leading them to look for alternative and more personal forms of religiosity. Because they had been following Orthodox beliefs and practices since childhood, they found it hard to totally break the chain of religious memory (Hervieu-Léger 2000) and thus reshaped them to be less doctrinal. For example, Maria, a 27-year old holding a degree in economics, was unable to find a job. Suffering from stress from what she perceived as a deadlock, she practiced mediation and yoga. I met Maria after her meditation session, and we attended the prayer service to St. Luke together. Maria did not want to stay for the whole service. She just wanted to light a candle, kiss the saint's icon, and wipe the icon with her handkerchief; she then used it to wipe her forehead. She firmly believed that both practices were curative in a similar manner-bestowing "positive energy" on her.

Before the crisis, my younger female interlocutors felt more empowered in the secular sphere and were more covert about exercising agency within the androcentric Orthodox environment, adapting church rules and prohibitions to individual needs through the ecclesiastical principle of oikonomia. A traditional concept stemming from Orthodox Canon Law, 
oikonomia basically refers to the mild application of church rules and prescriptions, particularly when applying them more strictly may lead someone to abandon the church. Thus, oikonomia provided the justification of more individualized ritual practices while keeping women within the limits of official belief and practice. During the crisis, the younger women's reaction against the patriarchal power structures of the church became more overt. Hardly any of them went to confession; rather, they "passed by" the church to receive Holy Communion, light candles, and kiss icons for help with a variety of secular concerns. They used sacred objects to gain "positive energy." Moreover, hardly any of them were taking part in the church's philanthropic activities. They were, thus, either totally rejecting or reshaping the meaning of Orthodox beliefs and practices. As Valia said, "when our mothers die, the churches will empty." Orthodoxy's "feminization" is hence seriously under threat.

\section{Conclusion}

The Greek crisis is having a pernicious impact on gender in the secular sphere, which is starting to permeate the religious sphere too. What I have described above is my modest contribution to the layout of a story which remains inconclusive. We have observed how nationality, sexuality, gender, religion, and the Greek crisis are intertwined through the reproduction of traditional stereotypes, discourses, and practices that exacerbate and further entrench preexisting power relations and structures. The male side of the story exhibits how the crisis endangers both the individual and the collective masculine self, and how religion becomes an important coping mechanism for men. The men of my study, particularly the younger ones, are both feeling and behaving as the prime victims of the current political and socioeconomic conditions. Being the main breadwinner, being Greek, and being Orthodox reassume a heightened significance for men during the crisis, leading them to participate more in church-related practices and philanthropic activities, which were previously characterized as feminine.

It would be wrong at this point, however, to talk about a "masculinization" of Greek Orthodoxy. Despite the shrinking female space, older women still remain deeply engaged with Orthodoxy, both in everyday practice, in church worship, and in the philanthropic activities of the church. The crisis, therefore, did not result in the "masculinization" of religion in Greece, but rather in the "feminization" of men. Their engagement with the church as victims of the crisis has an agentic character and is used as a tactic to achieve personal, economic, social, emotional, and spiritual benefits.

Moreover, I would argue that victimhood, as a conscious tactical mechanism, is more often adopted by my men interlocutors than by the women. This has largely to do with the fact that women, who are more often denied choices and more often subject to maltreatment and violence, are more reluctant to employ such tactics. Reacting against the official religious 
discourse that strongly defended traditional gender values as a cure to the crisis, the younger women of my study became openly anticlerical in their attitude, defying the priests' power and authority over them. Their agency is primarily expressed by the creation of an individual bricolage of spiritual and Orthodox practices, which helps them to deal with the insecurity and hardships of the crisis. In this sense, they are no longer "the traditional modern" (Sotiriu 2010) of the past, individualizing certain religious practices and beliefs yet firmly remaining within the bounds of Orthodoxy, but slowly becoming "the spiritual postmodern." Given the fact that during the crisis civil marriages have numerically exceeded religious ones and that, according to some of my interlocutors, baptisms are increasingly replaced by name giving (onomatodosia), younger women's religious behavior may further weaken the chain of religious memory. ${ }^{20}$ Crises do not necessarily involve a rupture with the past, but certainly do invite it. The Greek Orthodox hierarchy, thus, should definitely be on its guard.

\section{Notes}

1 To my knowledge only one study exists that focuses on the subject from a different perspective to the one adopted in this chapter. Spyridoula AthanasopoulouKypriou (2015), a feminist theologian, deals primarily with the question of whether the Greek Orthodox theological discourse can address the crisis, social injustice in general, and gender-based issues in particular.

2 For an analysis of religion from a power perspective, see Woodhead (2007); for religion as practice, see Gemzöe and Keinänen (2016, 13-15).

3 The names of my interlocutors have been changed.

4 For women's position in Greece before the crisis and the Greek feminist movement, see Gaitanou (2017).

5 All translations are by the author.

6 This proverb is originally attributed to the Greek dramatist Menandros (342/41-290 BC).

7 On the same point, see Bakalaki (2015).

8 On the tactics of accountability and blame, see Theodossopoulos (2013).

9 On the chronicities of the crisis in Greece and their normalization, see Cabot (2016).

10 On the entanglement of past, present, and future and how this is used by people in Southern Europe to make sense of their experiences of living with austerity, see Knight and Stewart (2016).

11 On prophecy and the merging of the metaphysical and the scientific spheres in future predictions during the crisis, see Yalouri (2016).

12 Greek Orthodox refugees from Asia Minor on Lesvos create and use sainthood in ways that have some parallels to the uses of saints under crisis conditions; this and their gender implications are discussed in Ray (2012).

13 On the feminization thesis and its critics, see Keinänen (2016).

14 On the same point, see Kessareas (2019).

15 On anticlerical feelings and men, see Herzfeld (1990, 309) and Just (1988).

16 On confession as a "modern moment" in an otherwise traditional Greek Orthodox Christianity and its association with Western psychotherapeutic ideas, see Thermos (2014).

17 See also Molokotos-Liederman (2012). 
18 For a similar analysis, see Douzina-Bakalaki (2017).

19 For a discussion on these points and the church's response to the crisis from 2009 to 2013, see Makris and Bekridakis (2013).

20 In 2013, the number of civil marriages was 25,632, while religious marriages numbered 25,624 (Hellenic Statistical Authority 2015, 23).

\section{Bibliography}

Athanasopoulou-Kypriou, Spyridoula. 2015. "The Gender Perspectives of the Economic Crisis in Greece and the Greek-Orthodox Church's Witness in Troubled Times: Charity Meals or a Quest for Justice?" Journal of the European Society of Women in Theological Research 23: 117-129. doi:10.2143/ESWTR.23.0.3103635.

Bakalaki, Alexandra. 2015. "Crisis, Gender, Time.” Allegralab, August 19. Accessed January 19, 2017. http://allegralaboratory.net/crisis-gender-time/.

Cabot, Heath. 2016. "The Chronicities of Crisis in Athens's Social Solidarity Clinics." Hot Spots: Cultural Anthropology Website, April 21. Accessed August 20, 2017. https://culanth.org/fieldsights/860-the-chronicities-of-crisis-inathens-s-social-solidarity-clinics.

Chiotis, Vasilis. 2015. "Poll Ká $\alpha \alpha$ Research: Orthodox Christians but ... Once a Year." To Vima, April 10. Accessed August 21, 2017. https://www.tovima. gr/2015/04/10/society/dimoskopisi-kapa-research-xristianoi-orthodoksoi-allamia-fora-ton-xrono/.

Dalakoglou, Dimitris, Georgios Agelopoulos, and Giorgos Poulimenakos. 2018. "De Te Fabula Narratur: Ethnography of and during the Greek Crisis." In Critical Times in Greece: Anthropological Engagements with the Crisis, edited by Georgios Agelopoulos and Dimitris Dalakoglou, 1-12. Abingdon: Routledge.

Douzina-Bakalaki, Phaedra. 2017. "Volunteering Mothers: Engaging the Crisis in a Soup Kitchen of Northern Greece.” Anthropology Matters 17 (1): 1-24.

Gaitanou, Eirini. 2017. "Fight Like a Girl': Social Movement and Feminism(s) amid the Crisis in Greece.” Feministische Studien 35 (2): 243-258. doi:10.1515/ fs-2017-0028.

Gemzöe, Lena, and Marja-Liisa Keinänen. 2016. "Contemporary Encounters in Gender and Religion: Introduction." In Contemporary Encounters in Gender and Religion: European Perspectives, edited by Lena Gemzöe, Marja-Liisa Keinänen, and Avril Maddrell, 1-28. Cham: Springer International Publishing / Palgrave Macmillan.

Glaros, Angela Christine. 2011. Singing Knowledge: Aesthetics, Authority, and Gender in Skyrian Music (Greece). Ph.D. Dissertation, University of Illinois at Urbana-Champaign.

Guyer, Jane I. 2007. "Prophecy and the Near Future: Thoughts on Macroeconomic, Evangelical, and Punctuated time." American Ethnologist 34 (3): 409-442. doi:10.1525/ae.2007.34.3.409.

Hellenic Statistical Authority. 2015. Greece in Figures (July-September 2015). Accessed January 22, 2018. http://www.statistics.gr/documents/20181/301069/ GreeceInFigures_2015Q3_EN.pdf.

Harrison, Pam. 2015. "Greek Debt Crisis: Tragic Spike in Suicide Rates.” Medscape, June 23, 2015. Accessed December 10, 2017. https://www.medscape.com/ viewarticle/846904\#vp_2a. 
Hervieu-Léger, Danièle. 2000. Religion as a Chain of Memory. New Brunswick, NJ: Rutgers University Press.

Herzfeld, Michael. 1990. "Pride and Perjury: Time and Oath in the Mountainous Villages of Crete.” Man 25: 305-322.

Hirschon, Renée. 2010. "Indigenous Persons and Imported Individuals: Changing Paradigms of Personal Identity in Contemporary Greece.” In Eastern Christians in Anthropological Perspective, edited by Chris Hann and Hermann Goltz, 289-310. Berkeley: University of California Press.

Just, Roger. 1988. "Anti-clericalism and National Identity: Attitudes towards the Orthodox Church in Greece." In Vernacular Christianity: Essays in the Social Anthropology of Religion, edited by Wendy James and Douglas Johnson, 15-30. New York: Lilian Barber Press.

Kantola, Johanna, and Emanuela Lombardo. 2017. "Gender and the Politics of the Economic Crisis in Europe." In Gender and the Economic Crisis in Europe: Politics, Institutions and Intersectionality, edited by Johanna Kantola and Emanuela Lombardo, 1-26. Cham: Springer International Publishing/Palgrave Macmillan.

Karamessini, Maria. 2014. "Structural Crisis and Adjustment in Greece." In Women and Austerity: The Economic Crisis and the Future for Gender Equality, edited by Maria Karamessini and Jill Rubery, 165-185. Abington: Routledge.

Keinänen, Marja-Liisa. 2016. "Feminist Reflections on the Study of the Feminization and Masculinization of Religion." In Contemporary Encounters in Gender and Religion: European Perspectives, edited by Lena Gemzöe, Marja-Liisa Keinänen, and Avril Maddrell, 55-75. Cham: Palgrave Macmillan.

Kessareas, Efstathios. 2019. "The Orthodox Church of Greece and Civic Activism in the Context of the Financial Crisis." In Religious Communities and Civil Society in Europe: Analyses and Perspectives on a Complex Interplay, Vol. 1, edited by Rupert Graf Strachwitz, 61-117. Berlin: De Gruyter Oldenbourg.

Kessareas, Efstathios. 2018. “The Greek Debt Crisis as Theodicy: Religious Fundamentalism and Socio-Political Conservatism." The Sociological Review 66 (1): 122-137. doi:10.1177/0038026117695491.

King, Ursula. 2005. "General Introduction: Gender-Critical Turns in the Study of Religion." In Gender, Religion and Diversity: Cross-Cultural Perspectives, edited by Ursula King and Tina Beattie, 1-12. London: Continuum.

Knight, Daniel M. 2013. “The Greek Economic Crisis as Trope." FocaalJournal of Global and Historical Anthropology 65: 147-159. doi:10.3167/ fcl.2013.650112.

Knight, Daniel, M., and Charles Stewart. 2016. "Ethnographies of Austerity: Temporality, Crisis and Affect in Southern Europe." History and Anthropology 27 (1): 1-18. doi:10.1080/02757206.2015.1114480.

McDowell, Maria Gwyn. 2013. "Seeing Gender: Orthodox Liturgy, Orthodox Personhood, Unorthodox Exclusion." Journal of the Society of Christian Ethics 33 (2): 73-92.

McGuire, Meredith, B. 2008. Lived Religion: Faith and Practice in Everyday Life. Oxford: Oxford University Press.

Mahmood, Saba. 2006. "Feminist Theory, Agency, and the Liberatory Subject: Some Reflections on the Islamic Revival in Egypt." Temenos: Nordic Journal of Comparative Religion 42 (1): 31-71. 
Makris, Gerasimos, and Dimitris Bekridakis. 2013. "The Greek Orthodox Church and the Economic Crisis 2009." International Journal for the Study of the Christian Church 13 (2): 111-132.

Makris, Gerasimos, and Vasilios Meichanetsidis. 2018. "The Church of Greece in Critical Times: Reflections through Philanthropy." Journal of Contemporary Religion 33 (2): 247-260.

Manika, Stella, and Aspa Gospodini. 2015. "Economic Downturn and Urban Landscape: Investigating Urban Shrinkage in a Middle-Sized Greek City: Larissa." Plurimondi VIII (16): 61-69.

Molokotos-Liederman, Lina. 2012. "Orthodox Social Service and the Role of the Orthodox Church in the Greek Economic Crisis.” Accessed March 25, 2017. http://www.faithineurope.org.uk/lina.pdf.

Nissinen, Martti. 2017. Ancient Prophecy: Near Eastern, Biblical and Greek Perspectives. New York: Oxford University Press.

Papataxiarchis, Evthymios, Pinelopi Topali, and Angeliki Athanasopoulou, eds. 2009. Worlds of Domestic Work: Gender, Migration and Cultural Transformations in Athens of the Early 21st Century (in Greek). Athens: University of the Aegean and Alexandria Publishers.

Paxson, Heather. 2004. Making Modern Mothers: Ethics and Family Planning in Urban Greece. Berkeley: University of California Press.

Rakopoulos, Theodoros. 2014. "The Crisis Seen from Below, Within, and Against: From Solidarity Economy to Food Distribution Cooperatives in Greece.” Dialectical Anthropology 38: 189-207. doi:10.1007/s10624-014-9342-5.

Ray, Séverine. 2012. "The Ordinary within the Extraordinary: Sainthood-Making and Everyday Religious Practice in Lesvos, Greece." In Ordinary Lives and Grand Schemes: An Anthropology of Everyday Religion, edited by Samuli Schielke and Liza Debevec, 82-97. New York: Berghahn Books.

Roussou, Eugenia. 2013. "Spirituality within Religion: Gendered Responses to a Greek 'Spiritual Revolution." In Gender and Power in Contemporary Spirituality: Ethnographic Approaches, edited by Anna Fedele and Kim E. Knibbe, 46-61. New York: Routledge.

Sakaranaho, Tuula. 2011. "Religion and the Study of Social Memory." Temenos: Nordic Journal of Comparative Religion 47 (2): 135-158.

Sotiriu, Eleni. 2010. “The Traditional Modern': Rethinking the Position of Contemporary Greek Women in Orthodoxy.” In Orthodox Christianity in 21st Century Greece, edited by Victor Roudometof and Vasilios N. Makrides, 131-153. Farnham: Ashgate.

Sotiriu, Eleni. 2004. "Contested Masculine Spaces in Greek Orthodoxy." Social Compass 54 (4): 499-510.

Stamos, Yannis. 2015. "Greece in Crisis: Culture and Politics of Austerity. Workshop Review.” Journal of Greek Media \& Culture 1 (2): 359-363.

Theodossopoulos, Dimitrios. 2013. "Infuriated with the Infuriated? Blaming Tactics and Discontent about the Greek Financial Crisis." Current Anthropology 54 (2): 200-221. doi:10.1086/669855.

Thermos, Vasileios. 2014. "'Love Your Neighbor as Yourself': The Encounter of Western Psychotherapeutic Ideas with the Orthodox Church in Greece." In Colonizing the Greek Mind? The Reception of Western Psychotherapeutics in Greece, edited by Charles Stewart, 65-82. Athens: Deree-The American College of Greece. 
Ware, Timothy. 1997. The Orthodox Church. New Edition. London: Penguin Books.

Woodhead, Linda. 2008. "Gendering Secularization Theory.” Social Compass 55 (2): 187-193.

Woodhead, Linda. 2007. "Gender Differences in Religious Practice and Significance." In The Sage Handbook of the Sociology of Religion, edited by James Beckford and N. J. Demerath III, 550-570. London: Sage.

Yalouri, Eleana. 2016. “'The Metaphysics of the Greek Crisis': Visual Art and Anthropology at the Crossroads." Visual Anthropology Review 32: 38-46. doi:10.111/var.12091. 